\title{
Nutritional and environmental factors affecting the morphogenesis of Candida albicans: A key to virulence
}

\section{Sayyada Ghufrana Nadeem and Aiman Pirzada*}

Department of Microbiology. Faculty of Science. Jinnah University for Women. Nazimabad. Karachi. Pakistan. *Email: a.pirzada174@gmail.com.

\begin{abstract}
Candida albicans is an opportunistic fungal pathogen that plays an important role in the early part of infectious process by extravagating and disseminating to the target organs, whereas hyphal forms appear to be required for the mortality resulting from a deep-seated infection. C. albicans morphogenesis is regulated by numerous environmental cues and other signaling pathways. We investigated the morphogenesis in $C$. albicans in the presence of serum at different temperatures $\left(20^{\circ} \mathrm{C}, 30^{\circ} \mathrm{C}\right.$ and $\left.37^{\circ} \mathrm{C}\right)$. C. albicans were also grown in simple growth medium 'SDB' and subsequently cultured from Fetal bovine serum and Soybeans dextrose broth (SDB) on Sabouraud dextrose agar, Yeast extract potato dextrose agar and Spider medium. The combination of serum and temperature is excellent at promoting the yeast to mycelial conversion and it also induces the expression of hyphal specific genes. Our results demonstrate that the combination of serum and each temperature provides a distinct proportion of blastospores, budding yeast cells, germ tube, pseudohyphae and true hyphal cells. Remarkable change in colonial pattern between the cells cultured after incubating in serum and the cells cultured after incubating in SDB was observed in SDA in contrast with YEPD and Spider medium. On most solid media, colonies of $C$. albicans are composed of three types of cells: budding yeast, pseudohyphae and hyphae. All three forms are also found in infected tissues, and the transition between these forms is a key for pathogenesis.
\end{abstract}

Keywords: Candida albicans; Virulence; Spider medium; Serum; Temperature.

\section{Introduction}

Candida albicans is a diploid asexual and dimorphic fungal organism and can be in existence as unicellular yeast (blastospores and chlamydospores) as well as in different filamentous forms (hyphae, pseudohyphae) (Molero et al., 1998). The severity of $C$. albicans infection often depends on the status of the host's immune system. However, the diversity in the pathogenicity of $C$. albicans strains suggests that strain related virulence factors do participate in disease severity (Navarro-Garcia et al., 2001). Morphogenesis has been a central point of research in $C$. albicans because 
virulence is linked with the ability of modification in yeast and hyphal morphologies. C. albicans reproduce vegetatively in three morphogenic types: yeast, pseudohyphae and hyphae (Gow, 2002). The important feature of $C$. albicans is its potential to grow either as blastospores, unicellular budding yeast and chlamydospores; as well as in pseudohyphal and hyphal forms (Sudbery et al., 2004). The colonies of C.albicans including hyphal and pseudohyphal cells march into the agar substratum. This characteristic enhances its tissue invasion during the primary phase of illness only, while the yeast form possibly is more appropriate for spread in the bloodstream. The pseudohyphal and hyphal forms are needed for the colonization of a variety of organs (Gow et al., 2002). Hyphae are consistently formed from un-budded yeast cells using the addition of serum along with a growth temperature of 37 ${ }^{\circ} \mathrm{C}$; with neutral $\mathrm{pH}$ also inducing hyphae and pseudohyphae in a culture medium. In recent times, it has been determined that high phosphate (equal to $600 \mathrm{mM}$ ) concentrations accelerate the pseudohyphae formation (Hornby et al., 2003).

Secondly, the presence of hyphae along with pseudohyphae triggers the smooth glistening colony towards crenulated appearance. Moreover, feathery projections are commonly originating from the outside edge of colonies that have many hyphal cells (Berman and Sudbery, 2002). The switching from yeast to hyphal morphology is also controlled by the interaction of $C$. albicans with microbial flora, present in C. albicans surroundings (Shareck and Belhumeur, 2011). C. albicans morphology is directly linked with the environmental conditions. Hyphae form in response to: serum (Taschdjian et al., 1960), neutral pH (Buffo et al., 1985), 5\% $\mathrm{CO}_{2}$ (the limited stress of $\mathrm{CO}_{2}$ within the bloodstream) (Mardon et al., 1969), $N$-acetyl-dglucosamine (GlcNAc) (Simonneti et al.,
1974) and increase growth in an embedded medium or in microaerophilic environment (Brown et al., 1999). Additionally, hyphal growth is frequently caused by the synthetic growth media namely Lee's medium (which have a combination of amino acids) (Lee et al., 1975), Spider medium (a semi-synthetic matrix based on mannitol as a 'C' source) (Liu et al., 1994) and mammalian tissue culture medium namely M199. In general, hyphal development needs a temperature of $37^{\circ} \mathrm{C}$; an exemption is filamentation in an embedded prevailing conditions and hypoxic growth that takes place at $25{ }^{\circ} \mathrm{C}$. The signaling pathways that convert environmental indications into morphological switching have been analyzed to a certain extent.

The serum and a temperature of $37{ }^{\circ} \mathrm{C}$ gives a strong signal for germ tube formation from yeast cells that came out as a classical diagnostic test for $C$. albicans in medical microbiology. Serum of different sources is the 'magical potion' that rapidly induces true hyphae in C. albicans (Feng et al., 1999). $N$ acetylglucosamine (GlcNAc) and proline are two factors produced by the degradation of serum (glycol-) proteins. Therefore, a range of self-regulating signaling pathways are maybe triggered by serum. Hyphae generate within minutes at $37^{\circ} \mathrm{C}$ and $5-20 \%$. Hyphae growth is triggered within a few hours on solid media. Several other compounds generate hyphae in vitro (Odds, 1988). The filamentous forms play a part during the disease expansion. During mucosal infections, the filamentous forms march into the epithelial as well as endothelial cells and cause damage, maybe during the release of hydrolytic enzymes (Dalle et al., 2010). This study has two major objectives, that is, to investigate the nutritional and environmental factors that induce morphogenesis in $C$. albicans and to demonstrate that the morphological plasticity induced by nutrients supplementation and environmental factors is often considered to be necessary for virulence. 
It is important to keep in mind that morphological variation is one of the many properties that have been shown to contribute to virulence.

\section{Materials and methods}

Primary isolation was done on Sabouraud's Dextrose Agar and the plates were incubated at $37^{\circ} \mathrm{C}$ for $3-4$ days. After that the secondary inoculum was prepared by taking a loop full culture of C.albicans in soybeans Dextrose Broth and incubated for $24 \mathrm{~h}$ at $37^{\circ} \mathrm{C}$. Culture was then centrifuged, supernatant was discarded, and the pellet was washed with PBS thrice. Inoculum size of $10^{6}$ cells was prepared by adjusting the fungal suspension to 0.5 McFarland (Maaroufi et al., 2004).

\section{For morphogenesis}

Three test tubes marked as control tubes and $1 \mathrm{~mL}$ of inoculums added plus $1 \mathrm{~mL}$ of fetal bovine serum (FBS) was added in each test tube and incubated at $20^{\circ} \mathrm{C}, 30^{\circ} \mathrm{C}$ and $37^{\circ} \mathrm{C}$, respectively for $2 \mathrm{~h}$. For the test, $1 \mathrm{~mL}$ of inoculums plus $1 \mathrm{~mL}$ of fetal bovine serum (FBS) suspension was prepared again in 3 tubes and incubated for $24 \mathrm{~h}$ at 20,30 and $37{ }^{\circ} \mathrm{C}$, respectively. Again, a new set of tubes was also prepared for comparison in which $1 \mathrm{~mL}$ of inoculums plus $1 \mathrm{~mL}$ of SDB was added and incubated for $24 \mathrm{~h}$ at $20{ }^{\circ} \mathrm{C}, 30^{\circ} \mathrm{C}$ and $37^{\circ} \mathrm{C}$, respectively. Afterwards the blastospores, budding yeast cells, germ tube, pseudohyphae, and hyphae were counted by microscope. For colonial morphology, a loop full of culture suspension was inoculated from each tube on Sabouraud's Dextrose agar, Yeast Extract Peptone Dextrose agar, and Spider medium agar plates and incubated for 5 days at $37^{\circ} \mathrm{C}$, the colonial morphology on each plate at different time intervals (after 48, 72, 98 and 120 h) was observed and recorded; pictures of colonies were taken every day.

\section{Results}

When $C$. albicans was grown in serum (FBS) at $20^{\circ} \mathrm{C}$ for $24 \mathrm{~h}, 63 \%$ of cells were remained in yeast form, $29.5 \%$ of cells started budding, $2.5 \%$ of cells produced pseudohyphae and $5.5 \%$ of cells formed germ tube (Figure 1). As the temperature increased to $30^{\circ} \mathrm{C}$, then the number of yeast cells or blastospores decreased to $50.5 \%$ and budding yeast cells were also decreased to $17.5 \%$. The number of pseudohyphal cells and germ tube increased to $17.5 \%$ and $14 \%$, respectively (Figure 2); and at $37{ }^{\circ} \mathrm{C}$ in presence of serum, the number of germ tube increased up to $31.5 \%$ of cells in comparison with $20^{\circ} \mathrm{C}$ and $30^{\circ} \mathrm{C}$. While the number of blastospores or yeast cells, budding yeast cells and pseudohyphal cells were reduced to $38.5 \%, 20.5 \%$ and $9.5 \%$, respectively (Figure 3), as compared to the growth of $C$. albicans at $20^{\circ} \mathrm{C}$ (Figure 4).

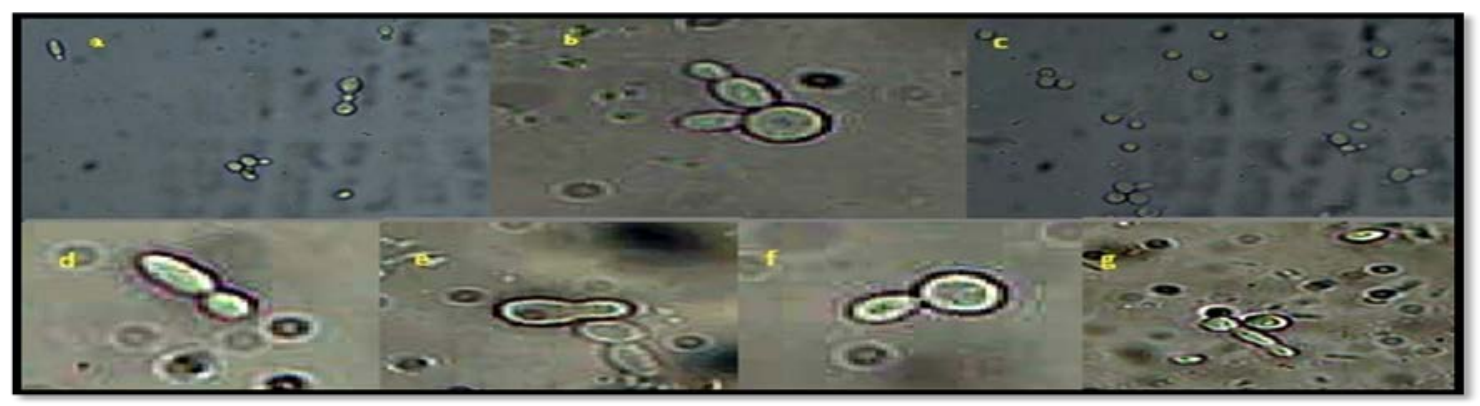

Figure 1. $20^{\circ} \mathrm{C}, 2 \mathrm{~h}$ in Serum; (a) Blastospores, Budding Yeast Cell, Germ tube, Pseudohyphae; (b) Pseudohyphae; (c) Blastospores, Budding Yeast Cells, Germ tube; (d \& e) Germ tube; (f) Budding Yeast Cells; (g) pseudohyphae at 40X. 


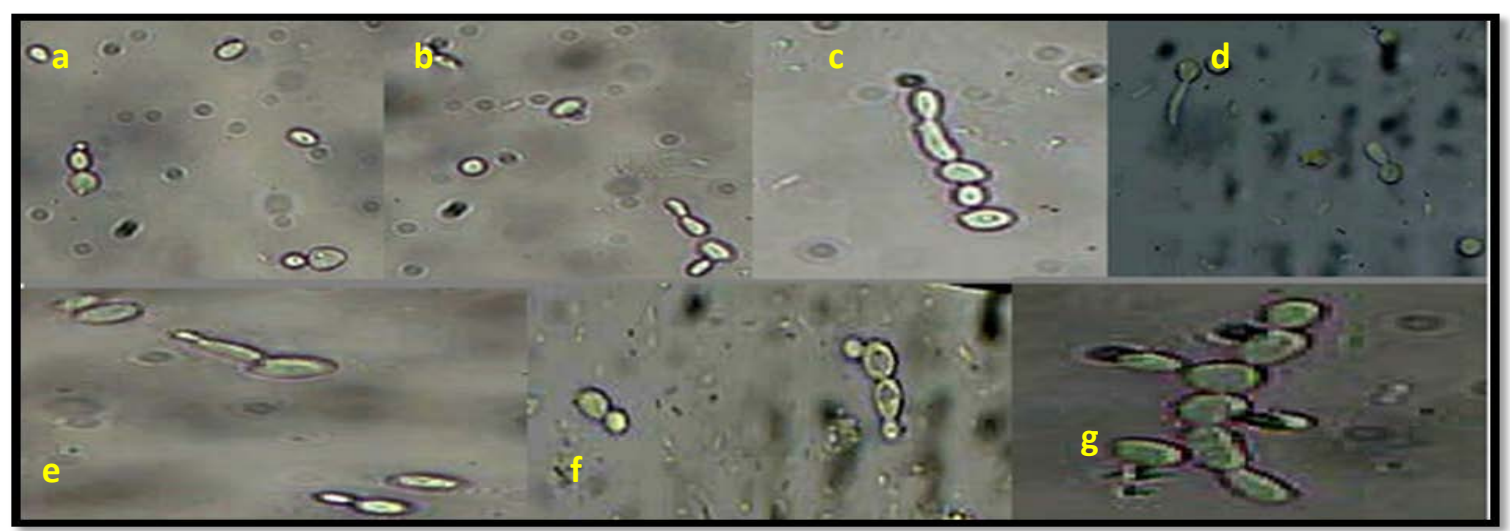

Figure 2. $30^{\circ} \mathrm{C}$, $2 \mathrm{~h}$ in Serum; (a) Blastospores, Budding Yeast Cells; (b) Blastospores, Budding Yeast Cells, Germ tube; (c) Pseudohyphae; (d) Blastospores, Germ tube; (e) Blastospores, Budding Yeast Cells, Pseudohyphae; (f) Budding Yeast Cells; (g) Pseudohyphae at 40X.

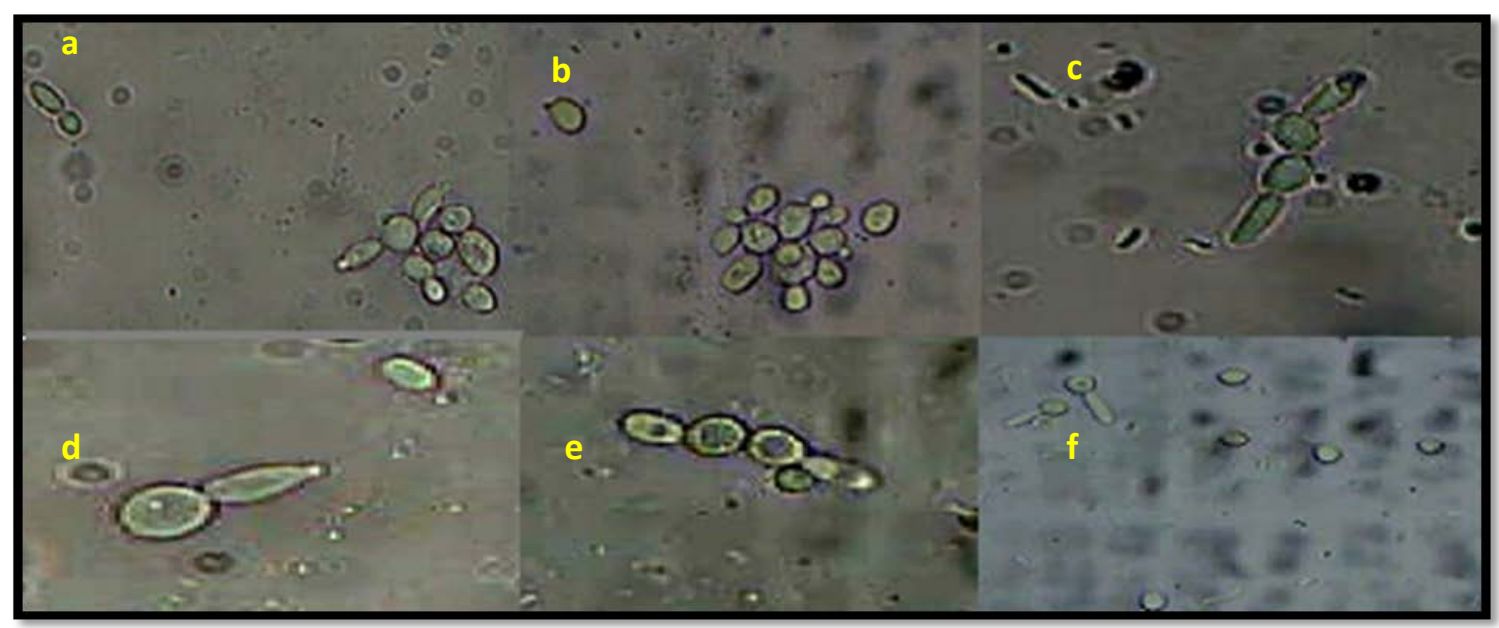

Figure 3. $37^{\circ} \mathrm{C}, 2 \mathrm{~h}$ in serum; (a) Blastospores, Budding Yeast Cells, Germ tube; (b) Blastospores, Budding Yeast Cells; (c) Germ tube; (d) Blastospores, Budding Yeast Cell; (e) Budding Yeast Cells; (f) Blastospores, Germ tube at 40X.

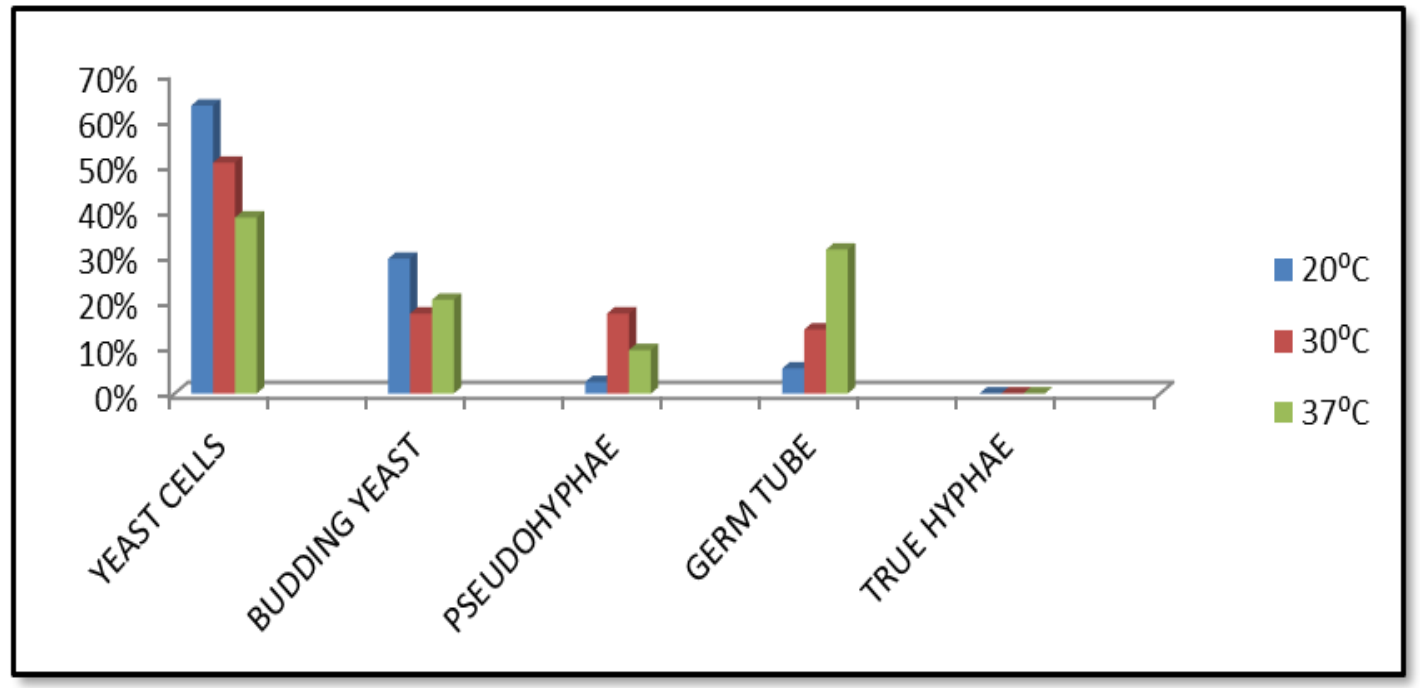

Figure 4. Growth of Candida albicans in Serum after $2 \mathrm{~h}$ of Incubation. 
Next, we analyzed the growth of C. albicans after $24 \mathrm{~h}$ of incubation in serum (FBS) at $20^{\circ} \mathrm{C}, 30^{\circ} \mathrm{C}$ and $37^{\circ} \mathrm{C}$ and we observed that the growth forms of the large number of cells were changed to germ tube and subsequently to mycelium or hyphal form. Therefore, at $20{ }^{\circ} \mathrm{C}$ we examined $19.5 \%$ hyphal cells, $6.5 \%$ germ tubes, $21.5 \%$ pseudohyphae, $12 \%$ of the cells produced buds and $40.5 \%$ of cells remained in yeast form (Figure 5). The temperature of $30{ }^{\circ} \mathrm{C}$ gave $31 \%$ of hyphal cells, $2.5 \%$ of germ tube, and $42.5 \%$ of pseudohyphal cells,
$13.5 \%$ of cells produced buds and $10.5 \%$ of cells remained as blastospores or yeast cells (Figure 6); and the combination of $37{ }^{\circ} \mathrm{C}$ and serum gave abundant number of true hyphal cells that is $65.5 \%$ of the cells in hyphal form, $5 \%$ of cells produced germ tubes; whereas pseudohyphal cells, budding yeast cells and blastospores were examined in lesser amount, that is, 9\%, $8 \%$ and $12.5 \%$, respectively (Figure 7 ); as the estimated growth shown in Figure 8.

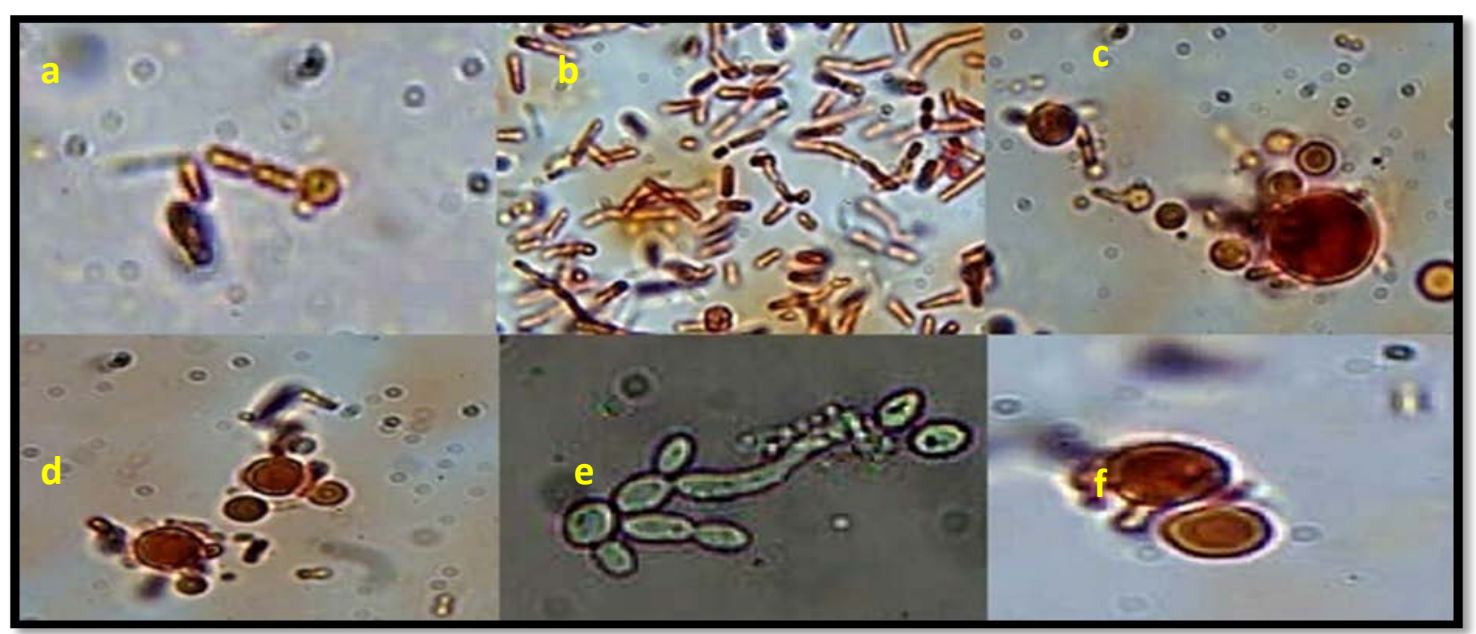

Figure 5. $20^{\circ} \mathrm{C}, 24 \mathrm{~h}$ in Serum; (a) Germ tube at 100X; (b) Hyphal Cells at 100X; (c) Blastospores, Germ tube at 100X; (d) Blastospores, Budding Yeast Cell at 100X; (e) Pseudohyphae at 40X; (f) Blastospores, Germ tube at 100X.

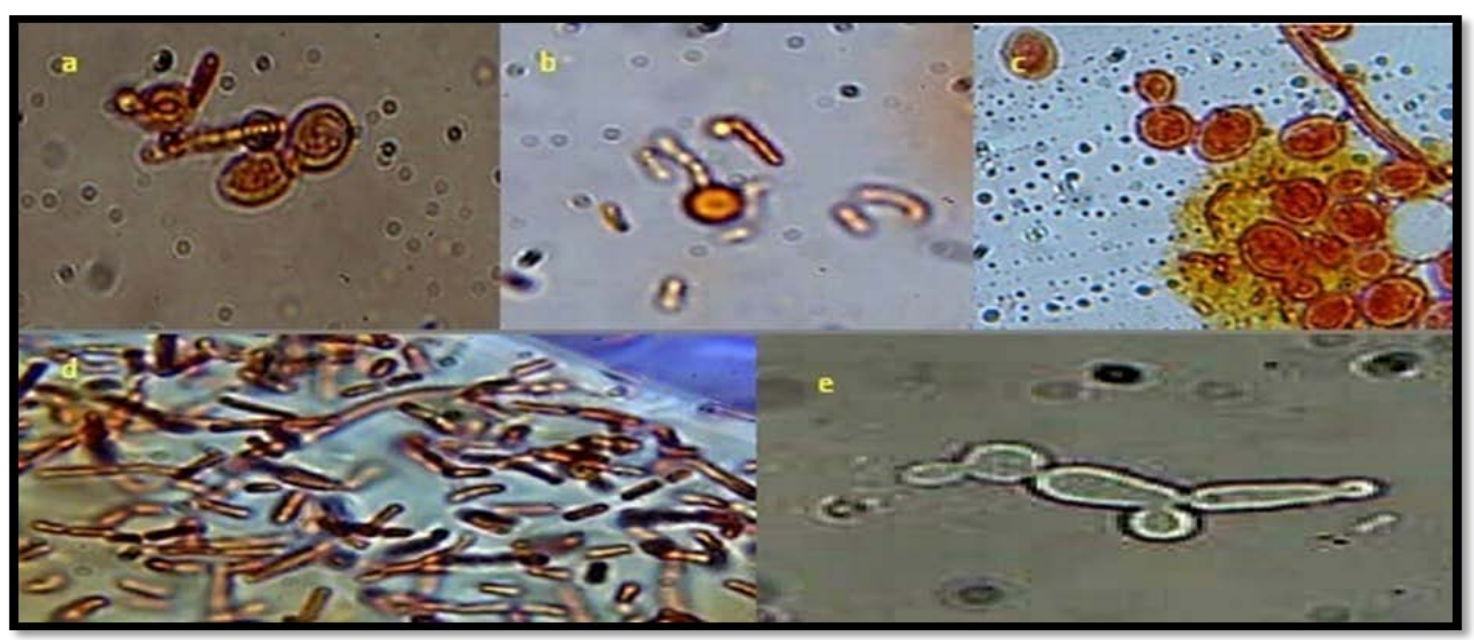

Figure 6. $30^{\circ} \mathrm{C}, 24 \mathrm{~h}$ in Serum; (a) Blastospores, Budding Yeast Cells, Hyphal Cells at 100X; (b) Germ tube at 100X; (c) Blastospores, Budding Yeast Cell at 100X; (d) Hyphal Cells at 100X; (e) Pseudohyphae at 40X. 


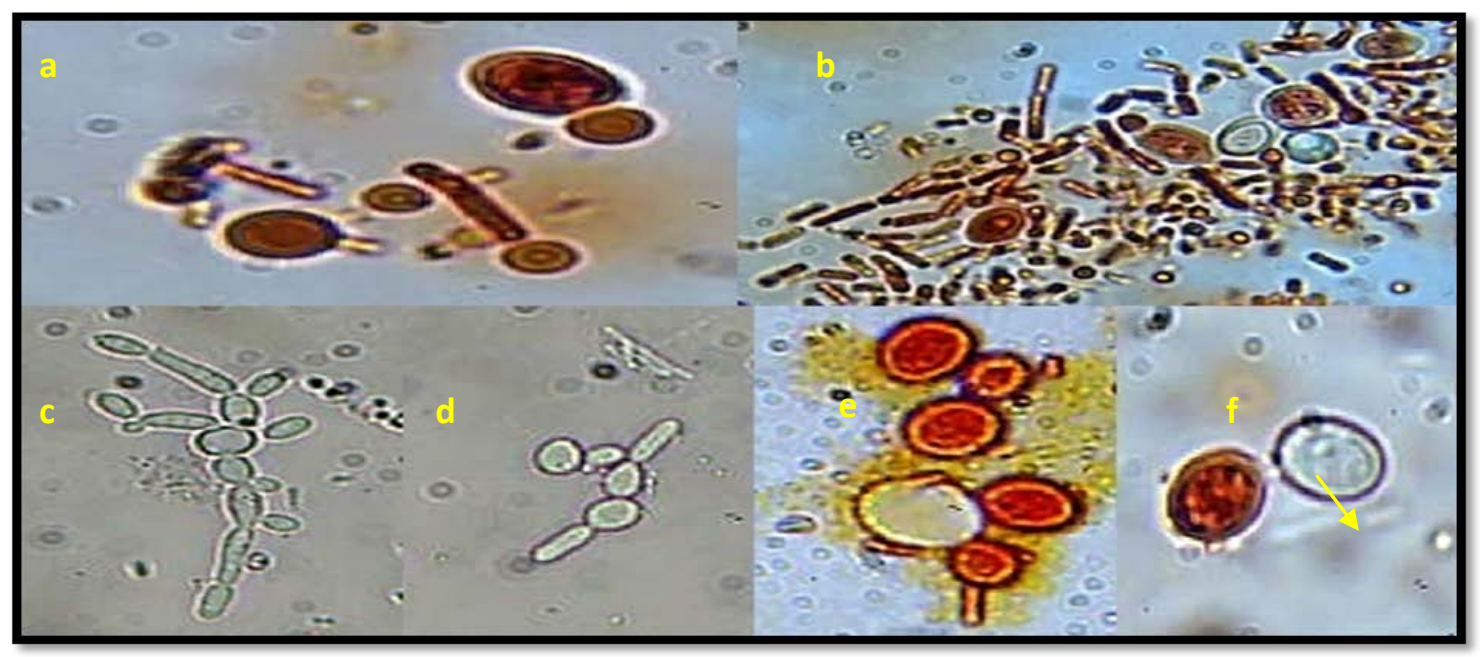

Figure 7. $37^{\circ} \mathrm{C}, 24 \mathrm{~h}$ in Serum; (a) blastospores, budding yeast cells, germ tube, hyphal cells at 100X; (b) blastospores, germ tube, hyphal cells at 100X; (c) pseudohyphae at 40X; (d) budding yeast cells, germ tube at 40X; (e) blastospores at 100X (f) Mating projection between two cells at $100 X$.

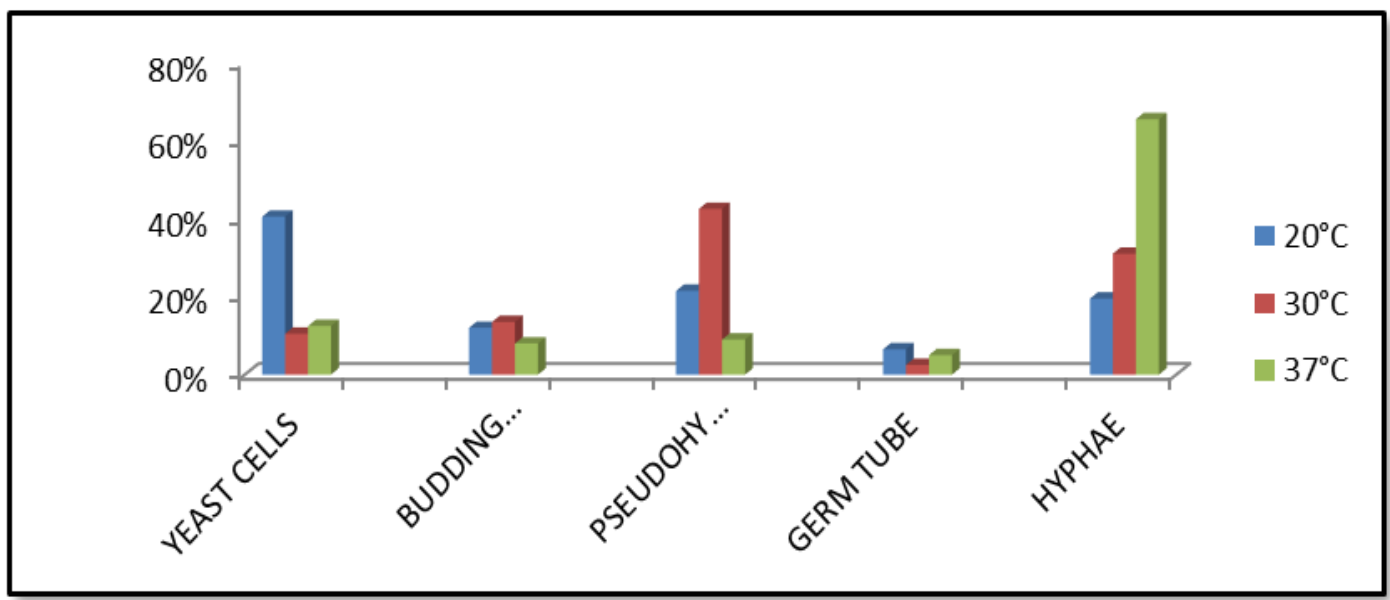

Figure 8. Growth of Candida albicans in Serum after $24 \mathrm{~h}$ of Incubation.

For the comparison of $C$. albicans growth in serum with the simple growth medium, we simply grew the inoculum cells in SDB and did not observe any hyphal cells in all three temperatures (Figure 9). In SDB at $20{ }^{\circ} \mathrm{C}$, we observed $62 \%$ blastospores or yeast cells, $30 \%$ of cells were in budding form and $8 \%$ of cells were in pseudohyphal form (Figure
10). Further in SDB at $30^{\circ} \mathrm{C}$ we observed $60.5 \%$ of yeast cells or blastospores, $31 \%$ of yeast in budding form and $8.5 \%$ were in pseudohyphal forms (Figure 11), when the cells were grown at $37^{\circ} \mathrm{C}$, only $1 \%$ of germ tube was observed, and $55.5 \%$ of blastospores, $22.5 \%$ of yeast cells and $21 \%$ pseudohyphae were observed (Figure 12). 


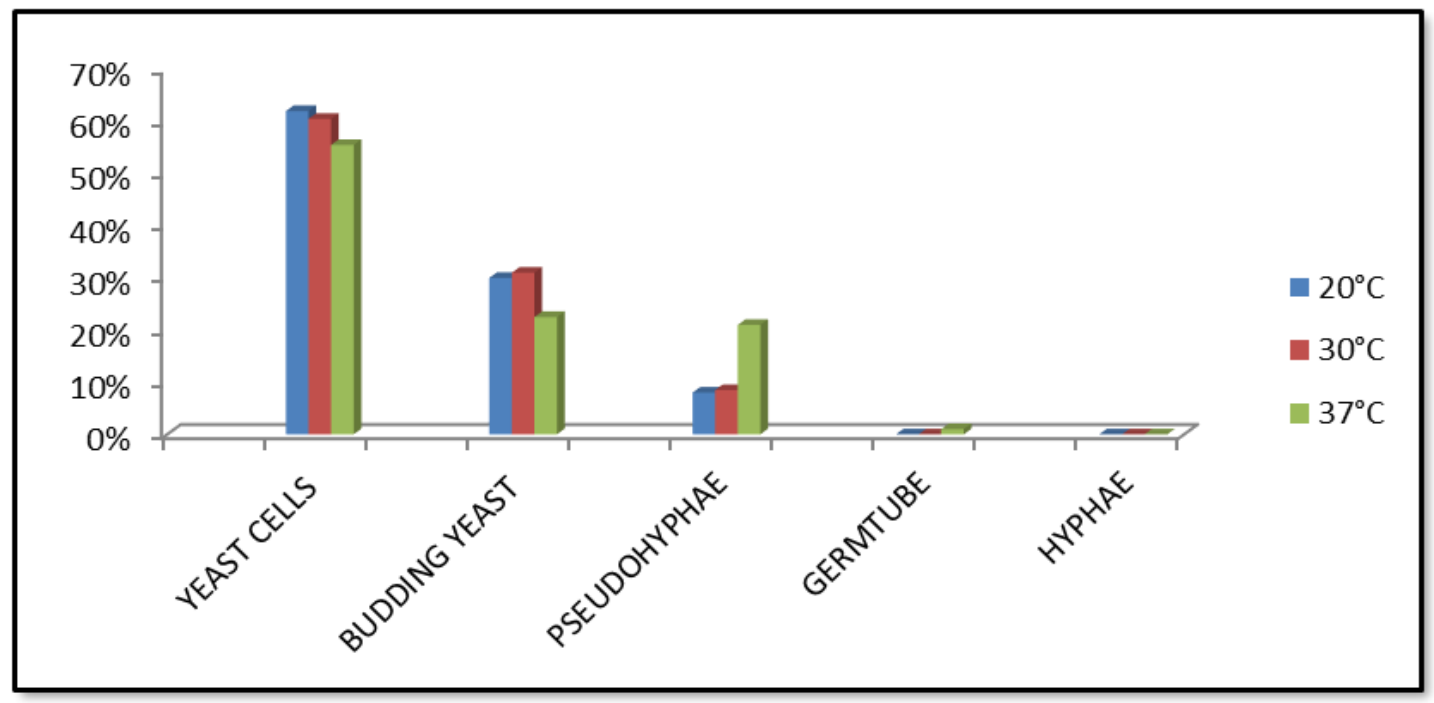

Figure 9. Growth of Candida albicans in SDB after 24h of Incubation.

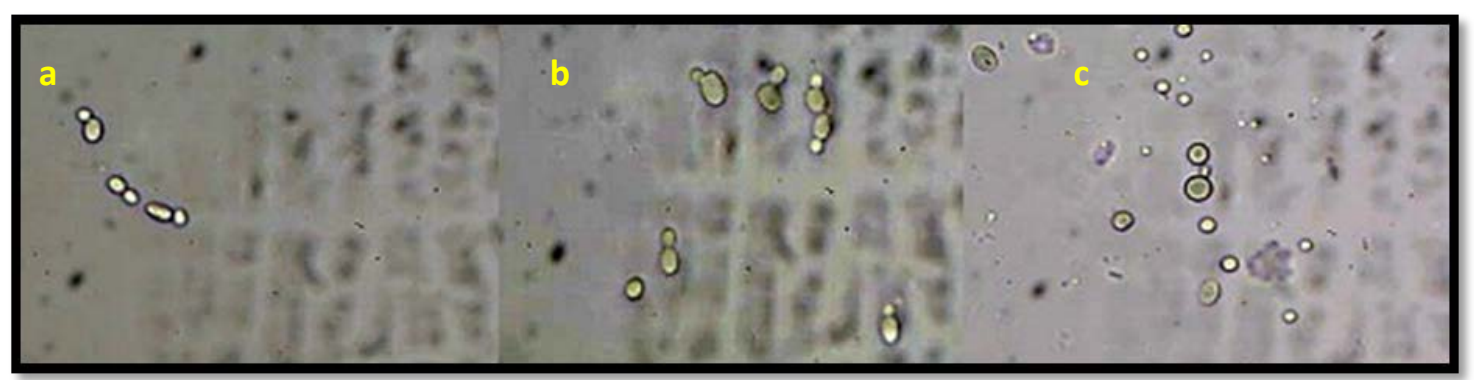

Figure 10. $20^{\circ} \mathrm{C}, 24 \mathrm{~h}$ in SDB; (a) Budding Yeast Cells; (b) Blastospores, Budding Yeast Cells; (c) Blastospores, Budding Yeast Cells at 40X.

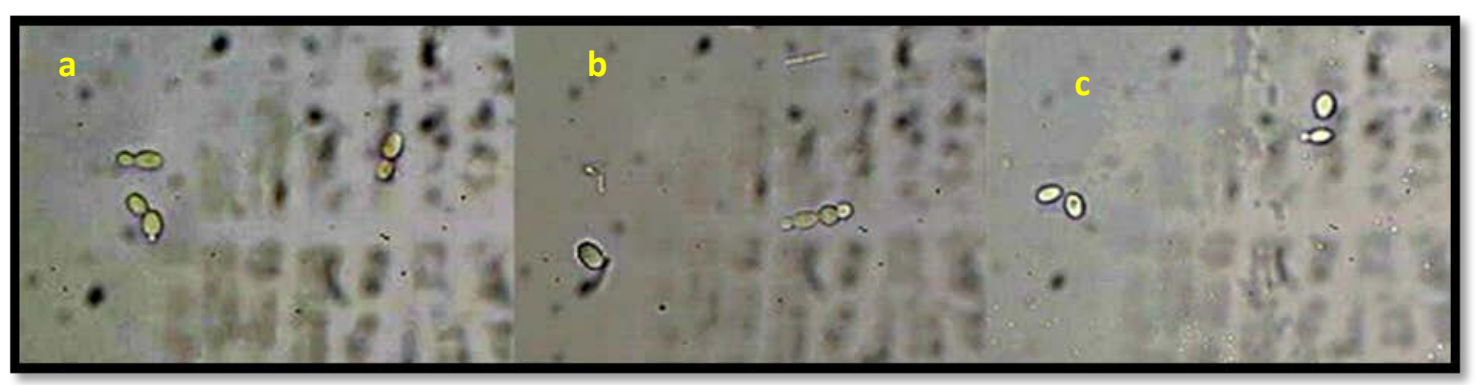

Figure 11. $30^{\circ} \mathrm{C}, 24 \mathrm{~h}$ in SDB; (a) Budding Yeast Cells; (b) Blastospores, Pseudohyphae; (c) Blastospores, Budding Yeast Cells at 40X.

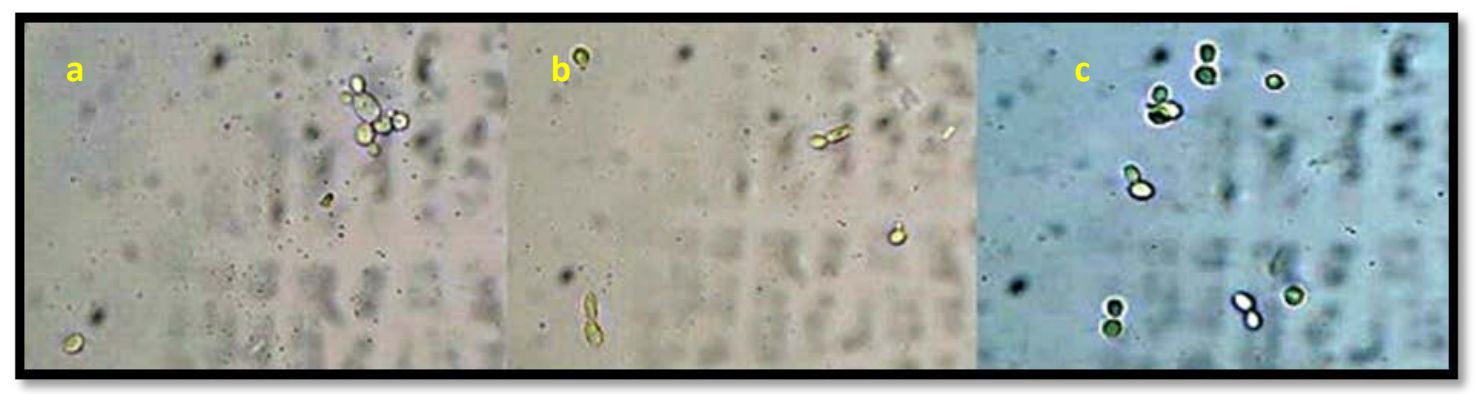

Figure 12. $37{ }^{\circ} \mathrm{C}, 24 \mathrm{~h}$ in SDB; (a) Blastospores, Budding Yeast Cells, Pseudohyphae; (b) Blastospores, Budding Yeast Cells; (c) Blastospores, Budding Yeast Cells at 40X. 
After observing morphogenesis in C. albicans under the microscope, the cells cultured in serum and SDB were inoculated on SDA, YEPDA and spider agar medium. Their colonial morphologies on different agars after different interval of time are demonstrated in Figure 13, 14, 15, 16, 17 and 18.

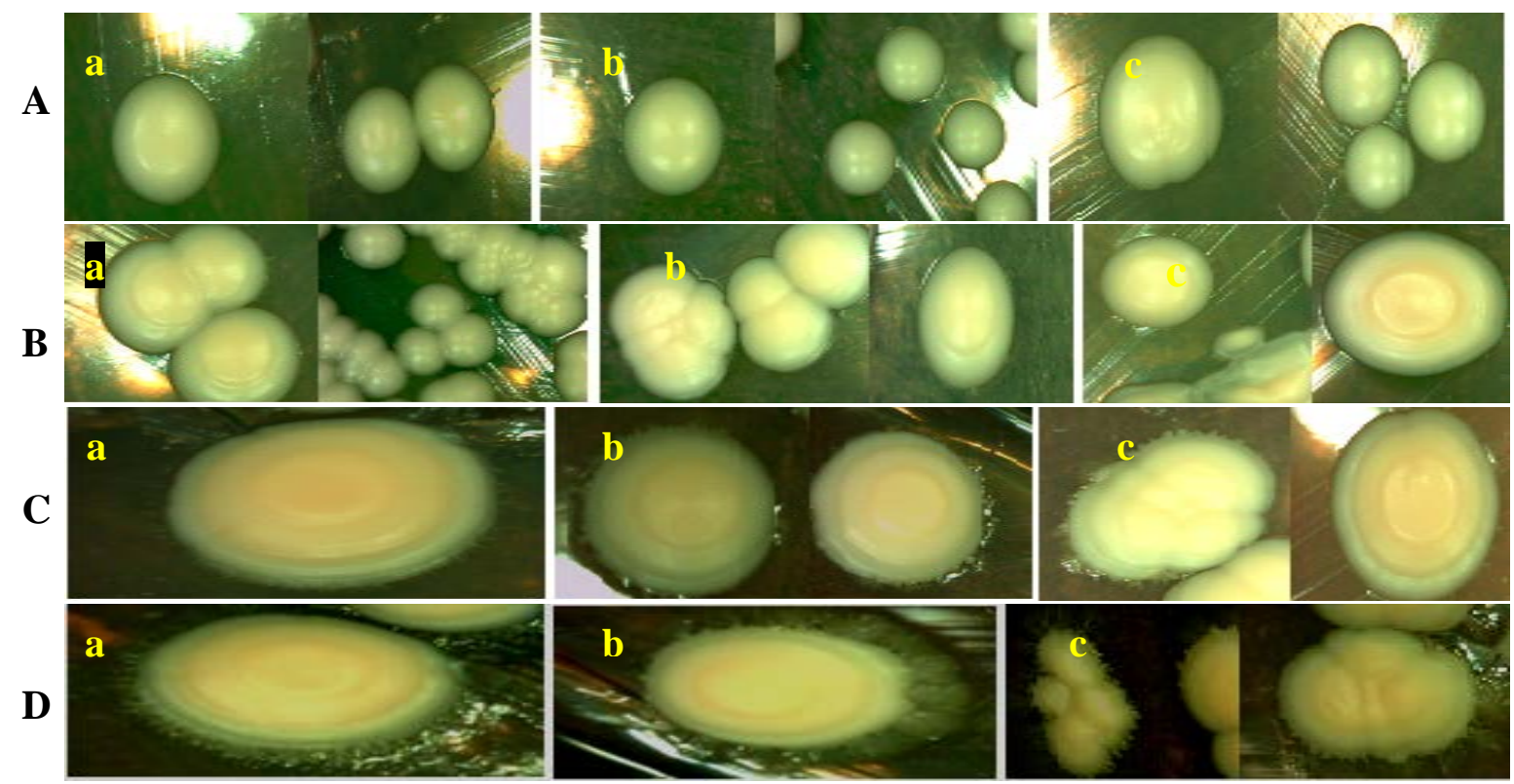

Figure 13. Colonial morphology of Candida albicans after incubation of cells in Serum: (a) at $20^{\circ} \mathrm{C}$ (b) at $30^{\circ} \mathrm{C}$ (c) at $37^{\circ} \mathrm{C}$. [A] Colonies grown for $48 \mathrm{~h}$; all colonies are rounded, smooth, glistening, and convex. But, the colonies are more yellow coloured at (c) as compare to (a, b). [B] Colonies grown for $72 \mathrm{~h}$; all colonies are rounded, smooth, glistening, a few are convex and some turn into umbonated shape. However, the colonies are more yellow coloured and more umbonated at (c) as compare to $(\mathrm{a}, \mathrm{b}) .[\mathrm{C}]$ Colonies grown for $98 \mathrm{hrs}$; all colonies are rounded, glistening, umbonated shape and concentric having filiform margins. Whereas, the colonies are more yellow coloured and more filamentous at (c) as compare to (a, b). [D] Colonies grown for 122hrs; all colonies are rounded, glistening, yellow coloured, become more filamentous, umbonated shape and concentric having filiform margins; While the colonies are more filamentous at (b) as compare to $(a, c)$. 

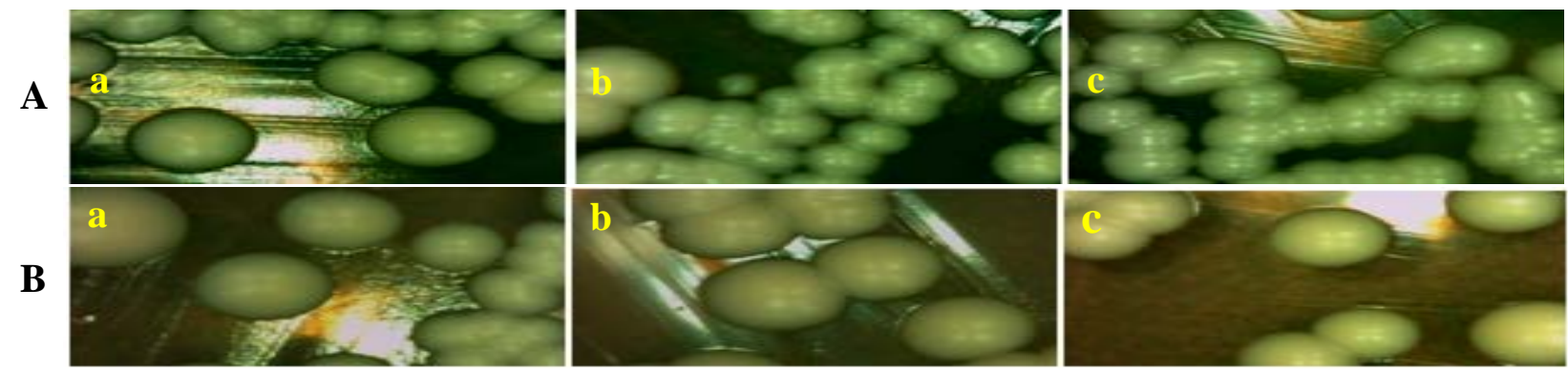

C
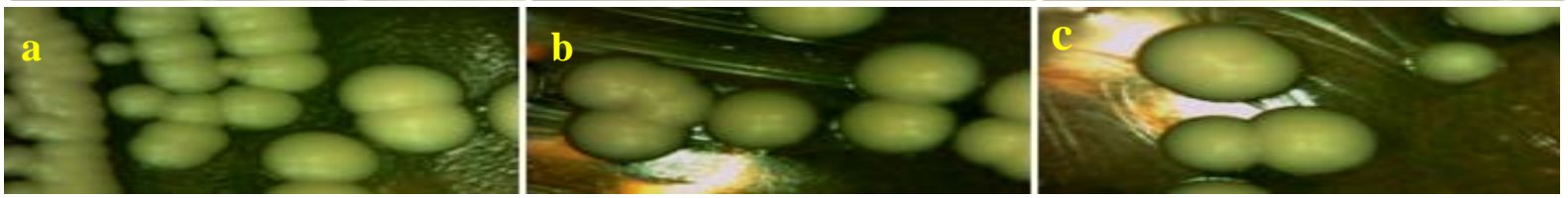

D
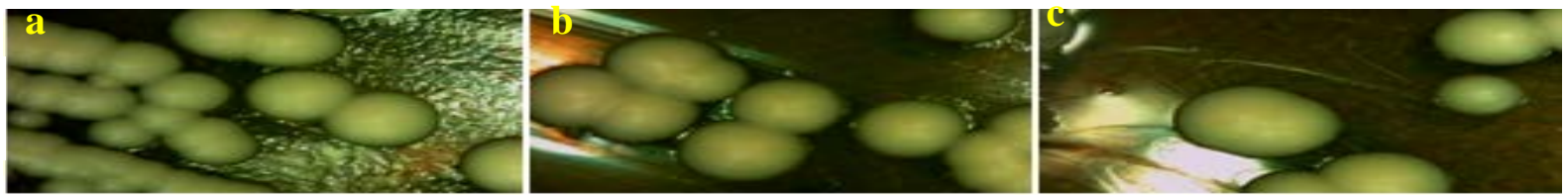

Figure 14. Colonial morphology of Candida albicans after incubation of cells in SDB (a) at $20^{\circ} \mathrm{C}(\mathrm{b})$ at $30{ }^{\circ} \mathrm{C}$ (c) at $37^{\circ} \mathrm{C}$. [A] Colonies grown for $48 \mathrm{hrs}$; all colonies are rounded, smooth, glistening, creamy and dome shaped. [B] Colonies grown for $72 \mathrm{hrs}$; all colonies are rounded, smooth, glistening, creamy, dome shaped and become larger than colonies of $48 \mathrm{hrs}$. However, colonies are slightly yellow in colour at (b, c) in contrast to (a). [C] Colonies grown for 98hrs; all colonies are rounded, smooth, glistening, and creamy and dome shaped. But, colonies are slightly yellow in colour at (b, c) in contrast to (a). [D] Colonies grown for $122 \mathrm{hrs;}$; all colonies are rounded, smooth, glistening, and creamy and dome shaped; whereas, colonies are slightly yellow in colour at (b, c) in contrast to (a). 


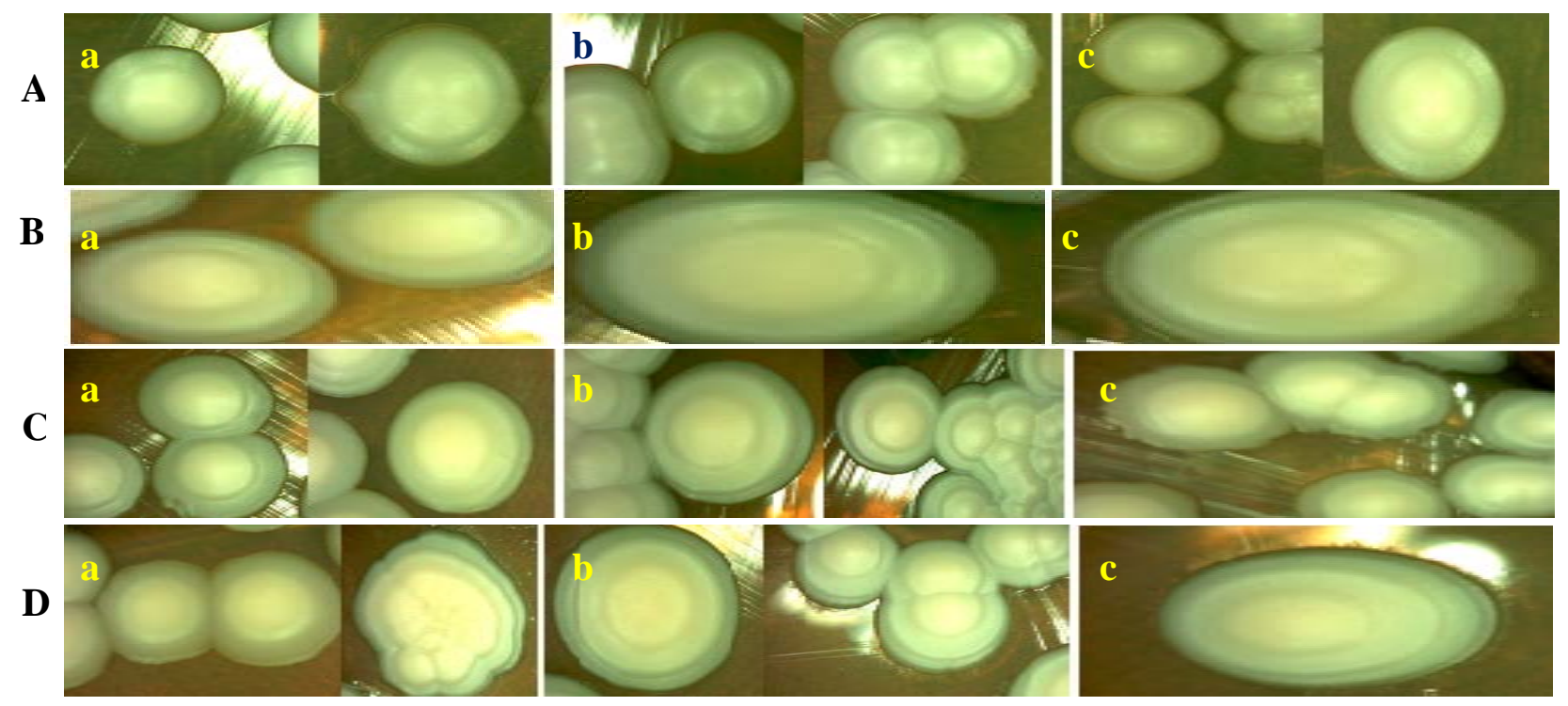

Figure 15. Colonial morphology of Candida albicans after incubation of cells in Serum (a) at $20^{\circ} \mathrm{C}$ (b) at $30^{\circ} \mathrm{C}$ (c) at $37^{\circ} \mathrm{C}$. [A] Colonies grown for $48 \mathrm{~h}$; all colonies are round, umbonated, glistening, dry, embedded, cream coloured, convex, towards periphery they showed light ring type structure and the ends are flat. [B] Colonies grown for $72 \mathrm{~h}$; all colonies are round, umbonated, concentric, glistening, dry, embedded, yellow coloured and convex. While the colonies of (c) have entire brown margins in contrast with $(\mathrm{a}, \mathrm{b})$. [C] Colonies grown for 98hrs; all colonies are round, umbonated, concentric, glistening, dry, embedded, yellow coloured and convex. However, a few of the colonies at $(a, c)$ are hat shaped having entire margins at ' $a$ ' and undulate margins at ' $c$ ' in contrast with colonies at (b). [D] Colonies grown for 122hrs; all colonies are round, umbonated, become more concentric, glistening, dry, embedded, yellow coloured and convex; Whereas, a few of the colonies at (c) have filiform margins in contrast with colonies at $(a, b)$. 


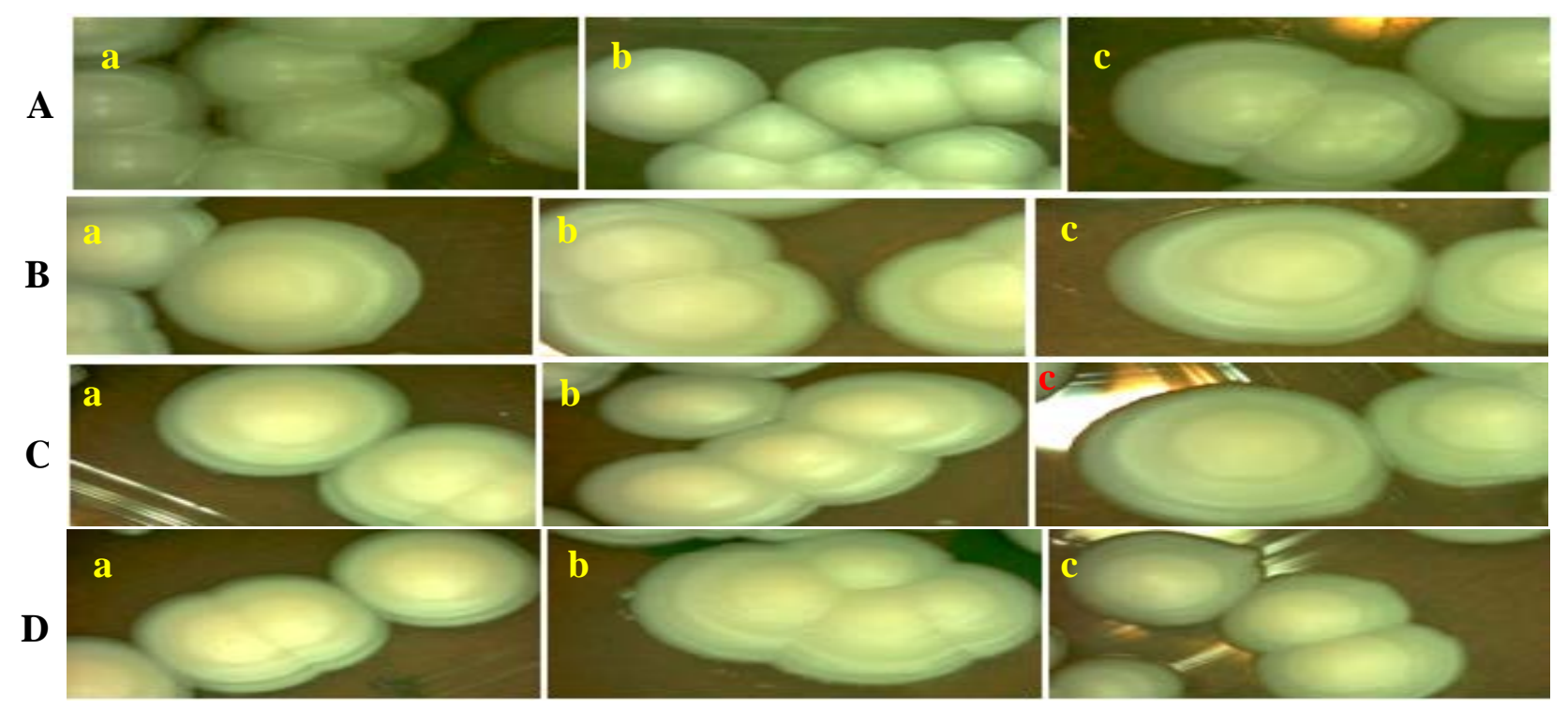

Figure 16. Colonial morphology of Candida albicans after incubation of cells in SDB (a) at $20^{\circ} \mathrm{C}$ (b) at $30{ }^{\circ} \mathrm{C}$ (c) at $37{ }^{\circ} \mathrm{C}$ [A] Colonies grown for $48 \mathrm{~h}$; all colonies are round, umbonated, glistening, dry, embedded, cream coloured, convex, towards periphery they showed light ring type structure and the ends are flat. [B] Colonies grown for $72 \mathrm{~h}$; all colonies are round, more umbonated, glistening, and dry, embedded, yellow coloured and convex. [C] Colonies grown for 98hrs; all colonies are round, umbonated, concentric, glistening, dry, embedded, yellow coloured and convex. [D] Colonies grown for $122 \mathrm{~h}$; all colonies are round, umbonated, concentric, glistening, dry, embedded, become more yellow in colour and convex. 
A
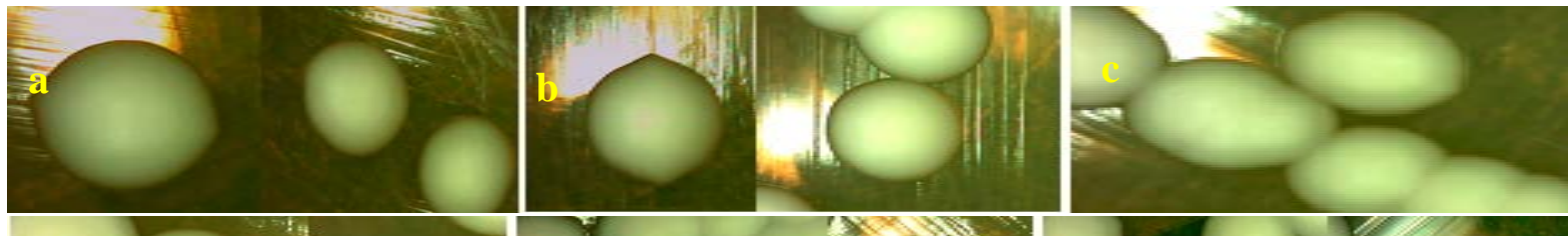

B
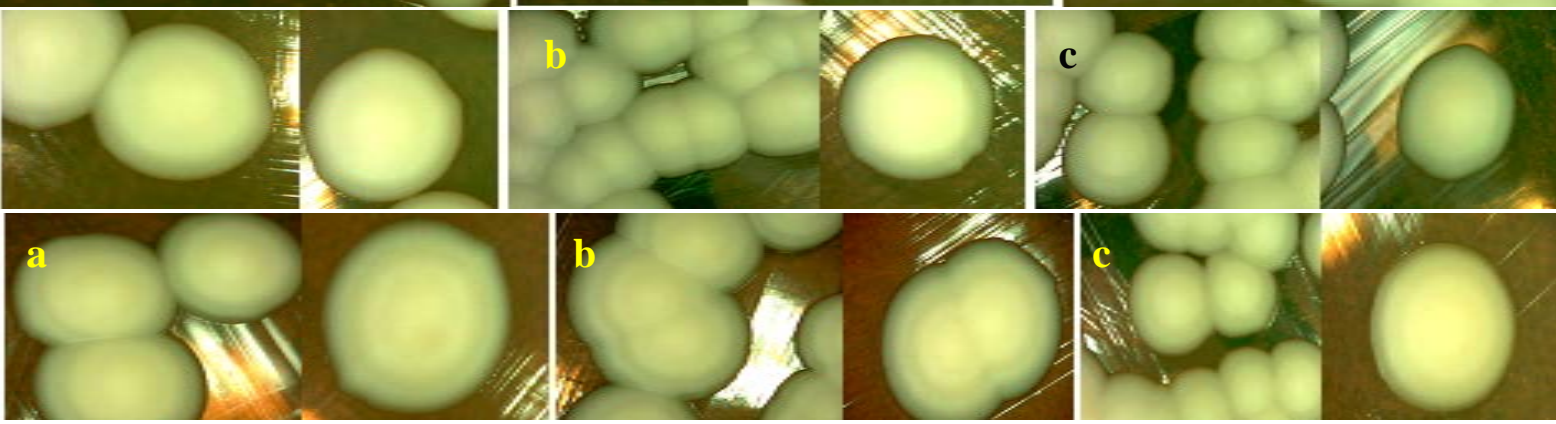

C
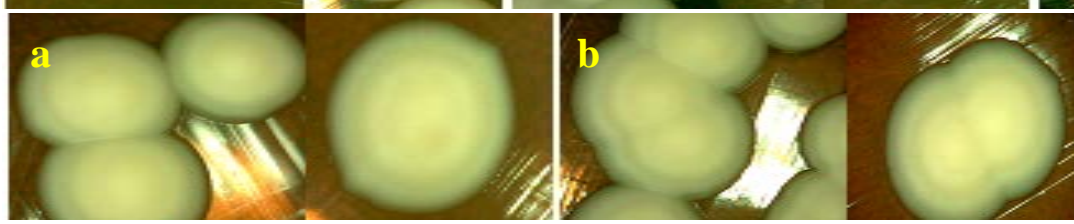

D
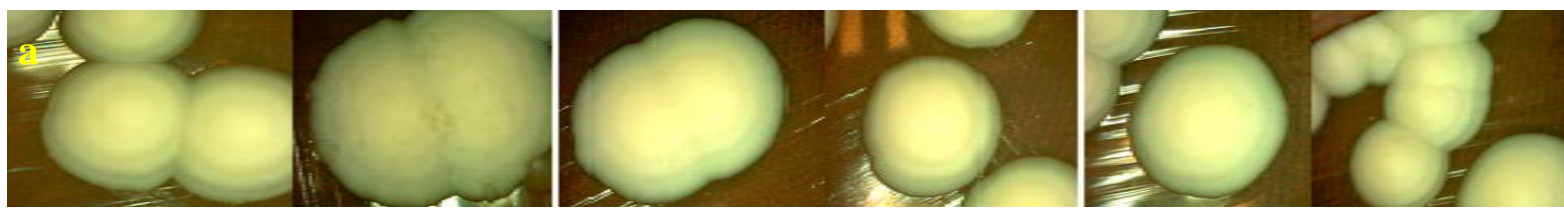

Figure 17. Colonial morphology of Candida albicans after incubation of cells in Serum (a) at $20{ }^{\circ} \mathrm{C}$ (b) at $30^{\circ} \mathrm{C}$ (c) at $37^{\circ} \mathrm{C}$. [A] Colonies grown for $48 \mathrm{~h}$; all colonies are embedded, some are irregular, and a few are circular, dull, rough, convex and cream coloured. [B] Colonies grown for $72 \mathrm{~h}$; all colonies are embedded, some are irregular, and a few are circular, dull, rough, convex, become concentric and cream coloured. [C] Colonies grown for $98 \mathrm{~h}$; all colonies are embedded, stipple centered, some are irregular, and a few are circular, dull, rough, convex, yellow coloured and surface become more concentric. [D] Colonies grown for $122 \mathrm{~h}$; all colonies are embedded, more stipple centered, some are irregular, and a few are circular, dull, rough, convex, yellow coloured and surface become more concentric. 
A
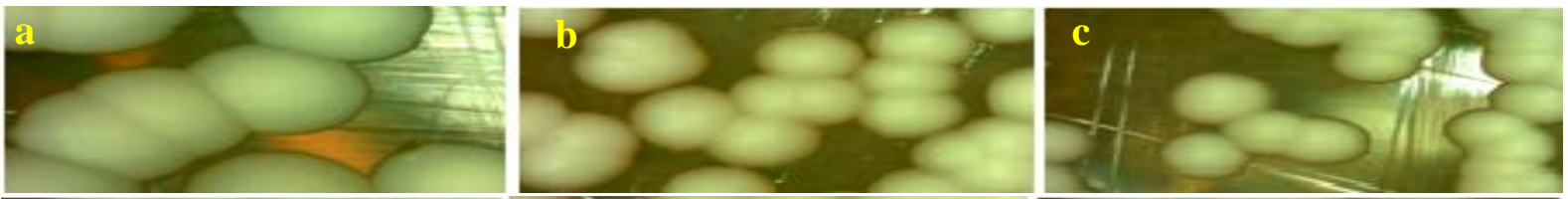

B
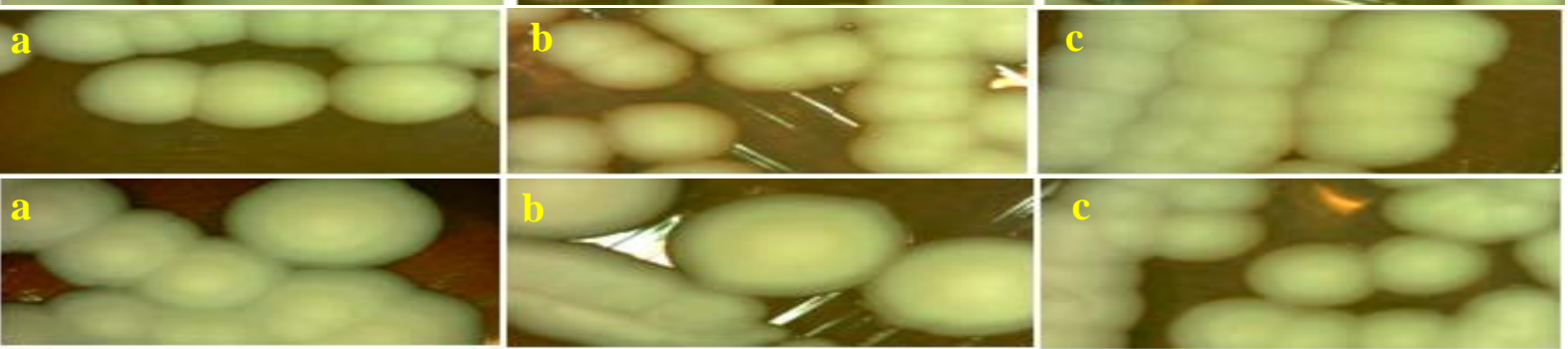

C
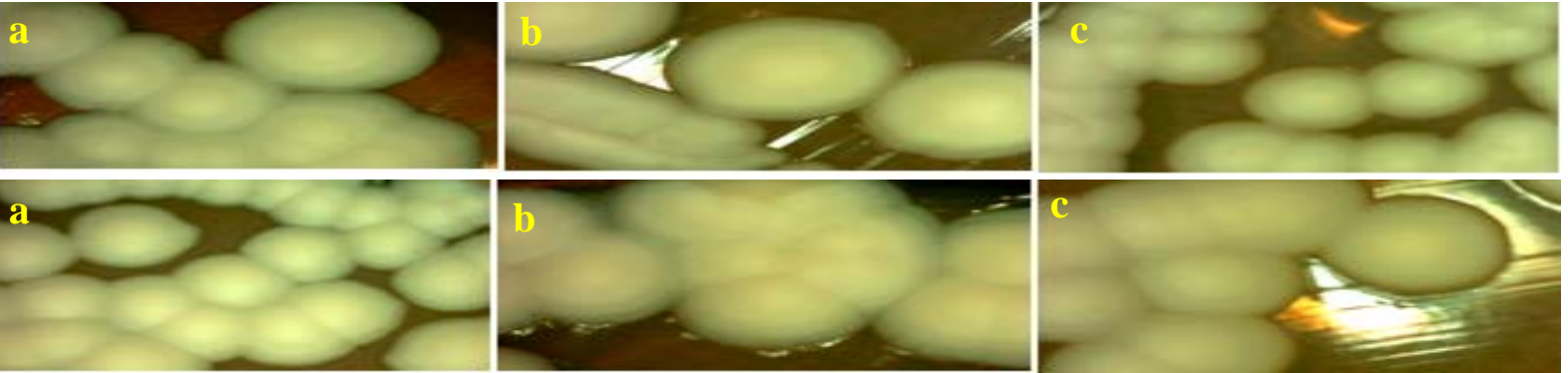

Figure 18. Colonial morphology of Candida albicans after incubation of cells in SDB (a) at $20^{\circ} \mathrm{C}$ (b) at $30^{\circ} \mathrm{C}$ (c) at $37^{\circ} \mathrm{C}$. [A] Colonies grown for $48 \mathrm{hrs}$; all colonies are round, rough, convex, dull, dry and cream coloured. [B] Colonies grown for $72 \mathrm{~h}$; all colonies are rounded, dry, dull, rough, convex and cream coloured. [C] Colonies grown for $98 \mathrm{~h}$; colonies are rounded shaped and a few are irregular shaped, dry, dull, rough, convex, concentric, cream coloured. [D] Colonies grown for $122 \mathrm{~h}$; colonies are rounded shaped and some are irregular shaped, dry, dull, rough, convex, concentric, umbonated, cream coloured.

\section{Discussion and conclusion}

C. albicans is a pathogenic fungus which has the ability to change the morphology in response to alterations in its growth environment (Brice and Malcolm, 2005). C. albicans virulence is identified to be affected by several environmental factors including temperature, $\mathrm{pH}$ and nutrient supplementation (Hazen and Hazen, 1987). In this study, C. albicans were incubated with fetal bovine serum at 20, 30 and $37^{\circ} \mathrm{C}$, to find out a combination of temperature and serum that has a profound effect on morphogenesis of $C$. albicans. We observed initial germ tube formation after $2 \mathrm{~h}$ and maximal filamentous growth of $C$. albicans after 24 $h$. Serum is considered as most efficient induction media known (Hudson et al., 2004).

Our results illustrated that after 2 $h$, the germ tube production was observed most at $37{ }^{\circ} \mathrm{C}$, moderate at 30 ${ }^{\circ} \mathrm{C}$ and lowest at $20{ }^{\circ} \mathrm{C}$; while pseudohyphae are abundant at $30^{\circ} \mathrm{C}$ and some of the yeast cells produce buds and some remain as blastospores at all temperatures. After $24 \mathrm{~h}$, yeast to truehyphae transition was maximum at 37 ${ }^{\circ} \mathrm{C}$, while yeast to pseudohyphae transition was maximum at $30^{\circ} \mathrm{C}$ as also reported by Barlow et al. (1974); while the one by one proportion of blastospores and budding yeast cells has not been reported by any researcher. Elevated temperature $\left(37^{\circ} \mathrm{C}\right)$ and serum, for instance, favour hyphal growth, whereas low temperature $\left(30^{\circ} \mathrm{C}\right)$ and the absence of serum stimulate yeast cell growth (Bachewich and Whiteway, 2005).

$$
\text { C. albicans develops }
$$
unconstricted hyphae in serumcontaining media that are divided into some discrete sections. Numerous studies have suggested that the growth 
medium that stimulates hyphal development are deprived of nitrogen and this hyphal growth imparts the hallmark of motility to a sessile cell, consequently permitting them to flee from the nutrient-deprived environments. Hyphae regress more rapidly to yeast forms in liquid medium, when any assimilable form of nitrogen is supplied with the serum (Barelle et al., 2003). In comparison with the growth of C. albicans in serum, we had also grown C. albicans in simple growth medium (soybeans dextrose broth) at 20, 30 and $37{ }^{\circ} \mathrm{C}$ and observed the combination of blastospores, budding yeast cells and pseudohyphae at all temperatures, while at $37{ }^{\circ} \mathrm{C}$ in SDB, C. albicans produced $1 \%$ germ tube. C. albican cells inoculated into YPD in the absence of serum at $30{ }^{\circ} \mathrm{C}$ remain in the yeast form, while $37{ }^{\circ} \mathrm{C}$ present normal germ tube production but are incapable of maintaining hyphal growth. Hence, serum in addition to a shift in temperature to $37{ }^{\circ} \mathrm{C}$ induces robust signals for hyphae formation and maintained hyphal growth as was reported by Yang et al. (2011). Majority of filamentous cells was observed at a temperature of $30^{\circ} \mathrm{C}$ in serum, were the pseudohyphal growth form instead of true hyphal forms; same findings were also reported by David and Alexander (2005). This is believed to be the first report on C. albicans colonial pattern using different agar medium with serum (FBS) at temperatures of 20, 30 and 37 ${ }^{\circ} \mathrm{C}$ for $24 \mathrm{~h}$. Colonial morphology acts as a sensitive assay for differentiation in the manner of cells through which these cells regulate the plasticity among three morphological types. On Majority of the solid media, colonies of C. albicans are comprised of three forms of cells: budding yeast (round cells), pseudohyphae (series of ellipsoidal cells that remain connected to one another after the cell division), and hyphae (highly elongated cylindrical cells that remain connected after cell division); therefore $C$. albicans displays a range of colony morphologies due to the conversions between these three forms. All these three types are also observed in infectious tissues and the conversion between these forms seem to be directly correlated to the pathogenesis (Homann et al., 2009). Generally, manner of budding of the yeast cells, the location of hyphae in the colonies and microenvironmental factors influence the colonies in the agar which also affect the colonial morphology in vitro (Pesti et al., 1999). Several genes induced in the blastospores-hyphal conversion made a hypothetical sensation. For instance, a significant proportion of the hyphalspecific genes code for cell wall components, a few of which are identified to function as adhesion vital for adherence to the host cells; it has been proven for many years that hyphae and blastospores vary in their adherence properties. The blastospores-hyphal conversion, involves the induction of 61 genes that is noticeably a significant feature of $C$. albicans virulence. Out of 61 genes induced by combination of serum and temperature, seven are recognized to be crucial for virulence in a mouse model of systemic Candidiasis (David and Alexander, 2005). Our results demonstrate the different colonial pattern of Candida on SDA after 5 days of incubation, that is, we observed filamentous or filiform colonies when the cells were transferred after $24 \mathrm{~h}$ of incubation in serum to the agar, while on the other hand we analyzed smooth, glistening, dome shaped colonies when the cells were shifted from SDB to SDA (as shown in Figure 4.1 and 4.2). On YEPD agar, was observed more concentric, darker yellow colored, irregular shaped and enhanced umbonated colonies after 5 days when cells were displaced after incubation in serum as compared to the colonies observed when cells following the growth in SDB for $24 \mathrm{~h}$ were transferred on the same agar medium as shown in Figure 5.1 and 5.2. On Spider agar, was observed duller, drier, rougher, reduced concentric and less umbonated colonies 
after 5 days of incubation when cells following growth in SDB were transferred to agar, quite the reverse was observed when $C$. albicans were displaced from the serum to spider medium then the colonies were comparatively dull, dry, less rough, more curled and enhanced umbonated as shown in Figure 6.1 and 6.2. This analysis showed that the prominent change of colonial pattern in between the cells transferred from serum (FBS) and the cells transferred from SDB was observed in SDA; this may be due to the difference of carbon source in between SDA and YEPDA mediums, as SDA contains dextrose where as YEPDA contains glucose and yeast extract. Alternatively, spider agar medium is itself nutrient deficient and stress inducing medium thus this might be the reason why no prominent disparity was observed among the colonies of $C$. albicans that contains cells transferred after $24 \mathrm{~h}$ of incubation in serum and after $24 \mathrm{~h}$ of incubation in SDB. In general, C. albicans can not only change its cellular morphology in response to growth conditions but can also irreversibly switch its cellular phenotype both in vitro and in vivo. The interactive processes in between host cell and $C$. albicans occur on the contact region linking the microbe and host cell surface and influence the microbial virulence. The microbial cell surface has some functions that are crucial for pathogenesis: invasion inside the host tissue, multiplication of microorganism in vivo, modification of host defense mechanisms, specificity host-tissue damage which depends on morphological transition.

Morphological switching also plays a part in altering the adherence properties, antigen expression, and colony morphology as well as tissue affinities in Candida albicans. Thus, the nature of connection in between morphogenesis and host incursion is an extremely discussed aspect of $C$. albicans virulence. The virulence of $C$. albicans is stimulated by growth in the serum and correlated with host body temperature. These virulence factors must help in adherence, invasion and proliferation, or support in resistance against innate immunity, evasion from adaptive immunity and facilitate in morphology variation. The most considerable indication for a factor to be taken into account as a virulence determining factor is the immediate loss of pathogenesis and the repossession of virulence when the factor is restored. This switching provides cells with a plasticity to bring about the adaptation of the organism to the unfriendly environment imposed not only by the host but additionally by the general practitioner treating the infection with the antifungal.

This morphological plasticity is most effortlessly examined in the morphology of colonies which are due to physiological and genetic variations. So, it is very important to keep an eye on different phenotypic variant of $C$. albicans by using simple yeast growth supporting medium available at low cost. These phenotypic differences are a product of differences in surface protein expression. The different surface protein expression results in differential adherence characteristics for the switch variants and differential sensitivities to neutrophils and phagocytic leukocyte killing. Thus, the differences in the phenotype may allow for increased resistance to immune attack or increased invasiveness. In general, filamentation is essential for C. albicans to evade from the process of phagocytosis and escape from the blood vessels. Biofilms formation in medical devices by the colonization of $C$. albicans depends on hyphal growth progression as well as on the manifestation of hyphae-specific gene products. Moreover, potentially fatal infections involving deep tissues result from the propagation of lethal strains of C. albicans throughout the body. The potential of a C. albicans to grow at $37^{\circ} \mathrm{C}$ in combination with serum is a virulence factor that invades deep tissue in host 
body. Therefore, yeast form represents the disseminating form of $C$. albicans whereas hyphae appear to be required for adherence and for penetration in the host cells or tissues. As pathogenesis is complex phenomenon, that is why possession of a single putative virulence factor is not enough for a fungus to become pathogenic; rather a complex combination of properties is usually required thus suggesting serum as a supporting growth medium and appropriate body temperature could enhance morphological switching; a key virulence factor of the organism that contributes to pathogenicity.

\section{Conflict of interest}

We declared that that there is no conflict of interest.

\section{References}

Barelle, C. J.; Bohula, E. A.; Kron, S. J.; Wessels, D.; Soll, D. R.; Schafer, A.; Brown, A. J.; Gow, N. A. Asynchronous cell cycle and asymmetric vacuolar inheritance in true hyphae of $C$. albicans. Eukaryotic Cell, v. 2, p. 398-410, 2003.

Barlow, A. J. E.; Aldersley, T.; Chattaway, F. W. Factors present in serum and seminal plasma which promote germ-tube formation and mycelia growth of $C$. albicans. Microbiology, v. 82, p. 261-272, 1974.

Berman, J.; Sudbery, P. E. C. albicans: a molecular revolution built on lessons from budding yeast. Nature Reviews Genetics, v. 3, p. 918-930, 2002.

Brice, E.; Malcolm, W. Release from QuorumSensing Molecules triggers hyphal formation during C. albicans resumption of growth. Eukaryotic Cell, v. 4, p. 1203-1210, 2005.

Brown, D. H. J. R.; Giusani, A. D.; Chen, X.; Kumamoto, C. A. Filamentous growth of $C$. albicans in response to physical environmental cues and its regulation by the unique CZF1 gene. Molecular Microbiology, v. 34, p. 651-662, 1999.

Buffo, J.; Herman, N.; Soll, D. R. A characterization of $\mathrm{pH}$ regulated dimorphism in C. albicans. Mycopathologia, v. 85, p. 21-30, 1985.
Bachewich, C.; Malcolm, W. Cyclin Cln3p Links G1 Progression to Hyphal and Pseudohyphal Development in C. albicans. Eukaryotic Cell, v. 4, p. 95-102, 2005.

Dalle, F.; Wachtler, B.; L'ollivier, C.; Holland, G.; Bannert, N.; Wilson, D.; Labruere, C.; Bonnin, A.; Hube, B. Cellular interactions of $C$. albicans with human oral epithelial cells and enterocytes. Cellular Microbiology, v. 12, p. 248-271, 2010.

David, K.; Alexander, D. J. Induction of the $C$. albicans filamentous growth program by relief of transcriptional repression: A genome-wide analysis. Molecular Biology of the Cell, v. 16, p. 2903-2912, 2005.

Feng, Q.; Summers, E.; Guo, B.; Fink, G. Ras signaling is required for serum-induced hyphal differentiation in C. albicans. Journal of Bacteriology, v. 181, p. 6339-6346, 1999.

Gow, N. A.; Brown, A. J.; Odds, F. C. Fungal morphogenesis and host invasion. Current Opinion in Microbiology, v. 5, p. 366-371, 2002.

Gow, N. A. R. Cell biology and cell cycle of Candida. In: Calderone, R. A. (Ed.). Candida and Candidiasis. Washington, D.C.: ASM Press, 2002. p. 145-158.

Hazen, K. C.; Hazen, B. W. Temperaturemodulated physiological characteristics of $C$. albicans. Microbiology and Immunology, v. 31, p. 497-508, 1987.

Homann, O. R.; Dea, J.; Noble, S. M.; Johnson, A. D. A Phenotypic Profile of the C. albicans Regulatory Network. PLoS Genetics, v. 5, e1000783, 2009.

Hornby, J. M.; Dumitru, R.; Nickerson, K. W. High phosphate (up to $600 \mathrm{mM}$ ) induces pseudohyphal development in five wild type C. albicans. Journal of Microbiological Methods, v. 56, p. 119-124, 2003.

Hudson, D. A.; Sciascia, Q. L.; Sanders, R. J.; Norris, G. E.; Edwards, P. J.; Sullivan, P. A.; Farley, P. C. Identification of the dialyzable serum inducer of germ-tube formation in $C$. albicans. Microbiology, v. 150, p. 3041-3049, 2004.

Lee, K. L.; Buckley, H. R.; Cambell, C. C. An amino acid liquid synthetic medium for the development of mycelial and yeast forms of C. albicans. Sabouraudia: Journal of Medical and Veterinary Mycology, v. 13, p. 148-153, 1975.

Liu, H. P.; Kohler, J. R.; Fink, G.R. Suppression of hyphal formation in C. albicans by 
mutation of a STE12 homolog. Science, v. 266, p. 1723-1726, 1994.

Maaroufi, Y.; De Bruyne, J.M.; Duchateau, V.; Georgala, A.; Crokaert, F. Early detection and identification of commonly encountered Candida species from simulated blood cultures by using a real-time PCR-based assay. The Journal of Molecular Diagnostics, v. 6, p. 108-114, 2004.

Mardon, D.; Balish, E.; Phillips, A.W. Control of dimorphism in a biochemical variant of $C$. albicans. Journal of Bacteriology, v. 100, p. 701-707, 1969.

Molero, G.; Diez Orejas, R.; Navarro Garcia, F.; Monteoliva, L.; Pla, J.; Gil, C.; Sanchez Perez, M.; Nombela, C. C. albicans: genetics, dimorphism and pathogenicity. International microbiology: the official journal of the Spanish Society for Microbiology, v. 1, p. 95-106, 1998.

Navarro, G. F.; Sanchez, M.; Nombela, C.; Pla, J. Virulence genes in the pathogenic yeast $C$. albicans. FEMS Microbiology Reviews, v. 25, p. 245-268, 2001.

Odds, F. C. Candida and Candidosis. Balliere Tindall: London, 1988.

Pesti, M.; Sipiczki, M.; Pinter, Y. Scanning electron microscopy characterization of colonies of $C$. albicans morphological mutants. Journal of Medical Microbiology, v. 48 , p. $167-172,1999$.
Shareck, J.; Belhumeur, P. Modulation of morphogenesis in $C$. albicans by various small molecules. Eukaryotic Cell, v. 10, p. 1004-1012, 2011.

Simonneti, N.; Stripolli, V.; Cassone, E.A. Yeast-mycelial conversion induced by $\mathrm{N}$ acetyl-d-glucosamine in C. albicans. Nature, v. 250, p. 344-346, 1974.

Sudbery, P.; Gow, N.; Berman, J. The distinct morphogenic states of $C$. albicans. Trends in Microbiology, v. 12, p. 317-324, 2004.

Taschdjian, C. L.; Burchall, J. J.; Kozinn, P.J. Rapid identification of $C$. albicans by filamentation on serum and serum substitutes. AMA Journal of Diseases of Children, v. 99, p. 212-215, 1960.

Yang, Lu.; Chang, Su.; Allen Wang; Haoping Liu. Hyphal Development in C. albicans requires Two Temporally Linked Changes in Promoter Chromatin for Initiation and Maintenance. PLoS Biology, v. 9, e1001105, 2011. 
Braz. J. Biol. Sci., 2018, v. 5, No. 10, p. 311-327. 